Research Article

\title{
Impact of Some Physiographic Factors on the Regeneration of the Species of Taxus Baccata L. on the Arasbaran Mountain Forests
}

\author{
Mir Mozaffar Fallah Chay * and Seyed Armin Hashemi.
}

Department of Forestry, Lahijan Branch ,Islamic Azad University, Lahijan, Iran.

Received 18 August 2012; Accepted 23 February 2013

\begin{abstract}
Taxus baccata L. is among the few indigenous and rare acerate-leaf trees of the Arasbaran forests facing extinction due to various reasons. In order to investigate the impact of some of physiographic factors on the natural regeneration of this species, two growing areas of Kolaleh with an area of 40 hectares and Kouran with an area of 46 hectares were selected from the Arasbaran forests. The sampling method was selective sampling with 43 pieces of circular samples of the shape 10. As to the same number, sub-plots of the nested type were selected and intended specifications were extracted. The results of this study showed that the regeneration of Taxus baccata L. increases upward with the increasing of the height above the sea level in the Kolaleh habitat and its most appropriate altitude is 1200-1300 meters. At the same time, the most appropriate altitude in the Kouran habitat is between 1400 and 1500 meters. The most regeneration of this species can be observed in the studied habitats in the northern foothills and the least regeneration can be seen in the northeast. In terms of the interrelationship between foothill slope and the frequency of regeneration, the highest percentage of reproduction took place in the Kolaleh habitat ( 46.48 percent in the slope of 51 to 60 percent). For the Kouran habitat, this value is about 58 percent for the slope of 41 to 50 percent, the reason for which may be associated to the raising of the soil's humidity and the increasing of surface soil in such slopes. Moreover, the results of Chi-square test (x2) showed that there's a significant discrepancy between the number of Taxus baccata L. regeneration and the heights and different directions in the level of $95 \%$ contingency.
\end{abstract}

Keywords: natural regeneration, Taxus baccata L., height, direction, slope, Arasbaran.

\section{Introduction}

Taxus baccata $\mathrm{L}$. is a skiophil species with a very slow growth and high longevity (more than 300 years) (Plaisance, 1979). It is also hygroscope and grows in the heights (Prioton, 1979). Its natural regeneration is generally weak and can be seen very rarely (Osareh, 2007). This species is one of the most environmentally valuable species of the Arasbaran forests in northwestern Iran and its global dissemination is very low because of its special ecologic needs and is considered to be one of the protected species facing the peril of extinction. As to the masses of Taxus baccata L. in the Arasbaran forests, it seems that this tree has been damaged mostly due to the human operations and what is seen today is not a result of the habitat-related and climatic conditions of the Taxus baccata $\mathrm{L}$ but a consequence of unrestricted destructions and exploitations in different time periods. The Arasbaran forests have been subject to serious destruction in the past and as one of the indigenous species of these forests, Taxus baccata L. hasn't been immune to the destructions; rather, as a result of having special and elite features, it was paid more attention by the exploiters. In Arasbaran, this tree has been removed from many forest regions and is observable in only a few parts.

\footnotetext{
*E-mail address: Mir_mozaffar@yahoo.com

ISSN: 1791-2377 @ 2013 Kavala Institute of Technology. All rights reserved.
}

The majority of the peduncles of Taxus baccata L. in these regions are coppice and mostly in the growth stages of sapling. Therefore, the most important objective of the present research is to study the impact of some of the most important physiographic factors such as height above the sea level, geographical dimensions and slope on regeneration of this rare natural species so that a more suitable management can be provided for such habitats by making an acquaintance of its living conditions. Many studies have been done about Taxus baccata L. and its regeneration status in the habitats of northern Iran the most important of which will be mentioned in passing. For example, Yousefpour Rashti (1998) has carried out a research about the regeneration status of Taxus baccata L. and the role of the quality of seed in its regeneration in the Guilan's Dorfrak region, or Hosseini (2000) has enumerated the human and ecologic factors as the main problems related to regeneration of Taxus baccata $L$. in studying the ecological power of the habitats of Iran's indigenous acerate-leaf trees. Ghanbari Sharafe (2005) has made investigations regarding the ecologic sequence and regeneration of Taxus baccata L. in the Arasbaran forests and has stated that Taxus baccata L. is going to develop in this habitat and is about to reach the climax societies. Abroad, Hulme (1996) has studied the impact of limitations which herbal plants create for Taxus baccata L. seeds in the UK. Moreover, Boyd (1995) has studied the style of scattering the seeds of Taxus baccata L. by the birds in the 
United States and investigated its impact on the growth of the juveniles of this species.

\section{Materials and methods}

The specifications of the region studied

In order to study the situation of Taxus baccata L. regeneration in the Arasbaran forests, the Kolaleh habitat in the Ilgene Chay region and Kourah habitat in the Hourand region were selected for this research because of having relatively intense and condensed masses of Taxus baccata L. Ilgene Chay is considered to be one of the most important forest habitats of Arasbaran which is located in the geographical position of longitude $46^{\circ} 34^{\prime}$ to $46^{\circ} 51^{\prime}$ east and latitude $38^{\circ} 48^{\prime}$ to $38^{\circ} 59^{\prime}$ north. Kolaleh habitat is located in the northeastern part of Ilgene Chay region with an area of 40 hectares, $85 \mathrm{~km}$ northwest of Kalibr. This is a mountainous region and the minimum and maximum of its height above the sea level varies between 816 meters around the Kolaleh village to 1600 meters at the elevated parts of the forest. In terms of municipal divisions, Hourand area is a subsidiary of Ahar city and Hourand district. The Kourah habitat has been developed in the longitude $47^{\circ} 25^{\prime}$ to $47^{\circ}$ $44^{\prime}$ east and latitude $38^{\circ} 55^{\prime}$ and $38^{\circ} 57^{\prime}$ north. With an area of 46 hectares, this habitat is located $35 \mathrm{~km}$ away from Hourand.

Pedology studies indicate that the soil of Kolaleh region in forest areas is of the type of brown forest soil and calcareous brown soil. Such soils are located on hard calcareous mother stones, marl and sand (Ghanbari Sharafeh, 2005). The soil of Kouran region in the forest lands is calcareous brown, located on chert limestone, sand limestone and thin marl layers (Alizadeh, 2006). $\mathrm{Ph}$ of the soils has varied between 7 and 8 and the average annual precipitation in these regions has been $432.5 \mathrm{~mm}$ and the average temperature stood at $11.5^{\circ}$. According to the Amberge method, the climate of the region is semi-arid and cold.

\section{Methodology}

In the present study, the number of measured sample plots was determined using selective sampling. Accordingly, 43 plots of 10 shape and 43 sub-plots of 1 shape with a radius of 5.64 meters were selected in a nested form plot. In the sample plots, the specifications of diameter at breast, the height of tree, the slope of the region, the direction of slope and height above the sea level were measured and recorded. In order to investigate the situation of regeneration under the selected plots of the saplings, their health and vivacity status was determined and the collected data were saved as a database in the SPSS software. Moreover, the nonparametric Chi-square of the separated groups in terms of height above the sea level, directions and their slopes were analyzed with quantitative and qualitative specifications of regeneration (Farsi, 2008).

\section{Results}

According to figure (1), it can be seen that the greater part of regeneration of the Taxus baccata $L$. and other species in the Kolaleh habitat is dedicated to 1200-1300 meter elevation. Also, it is observed that in this habitat, regeneration has an upward course with the increasing of height above the sea level. Up to the height of 1300 meters, this course will be appropriate and then decreases. In the Kouran habitat, the majority of regeneration of Taxus baccata L. and other species belong to the elevation of 1400-1500 meters and then with the increasing of the height above the sea level, the regeneration will decrease (Figure 2).

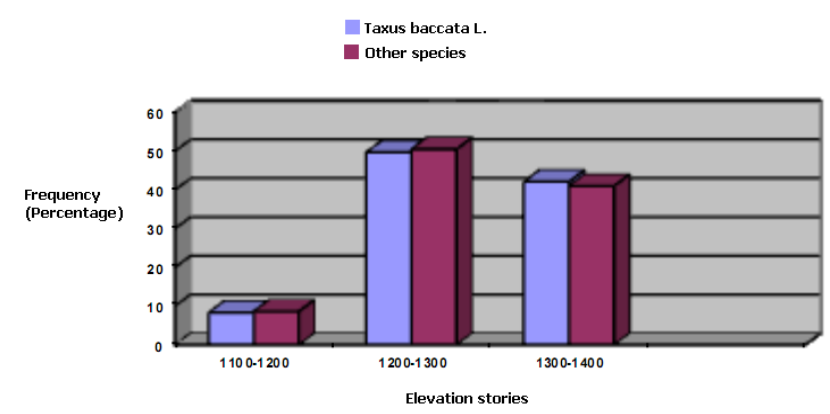

Fig. 1. The interrelationship between height above the sea level and the frequency of regeneration in the Kolaleh habitat

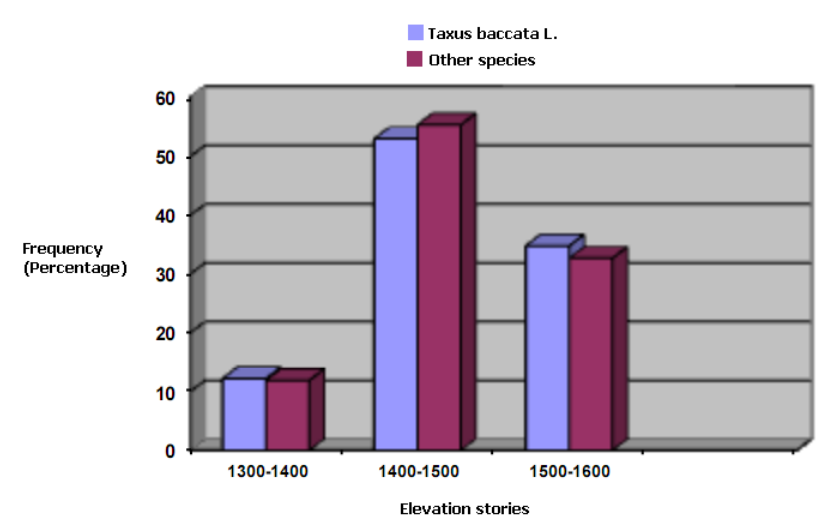

Fig. 2. The interrelationship between height above the sea level and the frequency of regeneration in the Kouran habitat

\section{Geographical dimensions}

According to figure 3, the northern foothills of Kolaleh habitat account for the most regeneration with $67.12 \%$ while the northeastern foothill account for the least regeneration with $16.2 \%$. Moreover, given the information included in the figure 4 , it can be seen that in the Kouran habitat, the northern foothills have the most and the northeastern foothills have the least regeneration with $78.75 \%$ and $4.25 \%$ respectively.

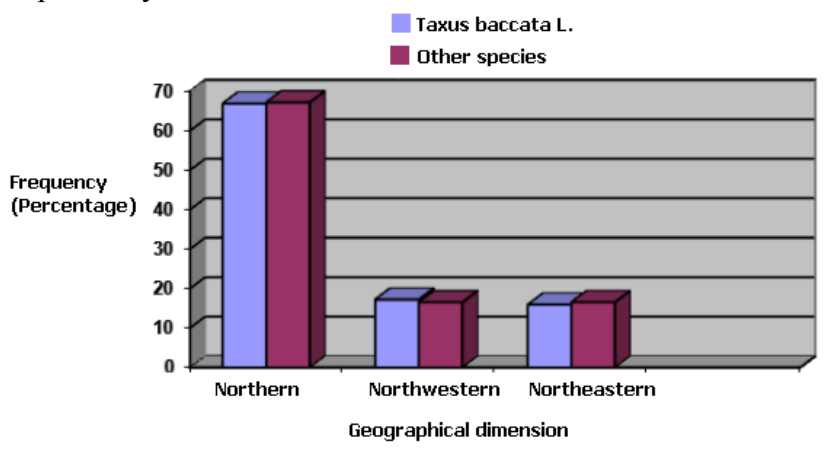

Fig. 3. The interrelationship between geographical dimensions and the frequency of regeneration in the Kolaleh habitat 


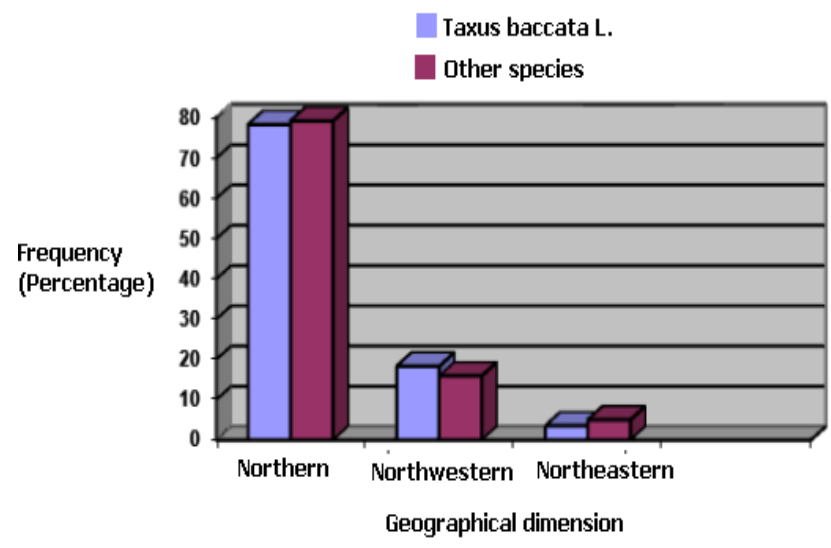

Fig. 4. The interrelationship between geographical dimensions and the frequency of regeneration in the Kourah habitat

\section{Slope}

According to the figure 5, the greater part of the frequency of regeneration and accompanying species in the Kolaleh habitat belongs to the $51-60 \%$ slope with a value of $46.48 \%$ while the same value stands at $58 \%$ for the slope of $41-50 \%$.

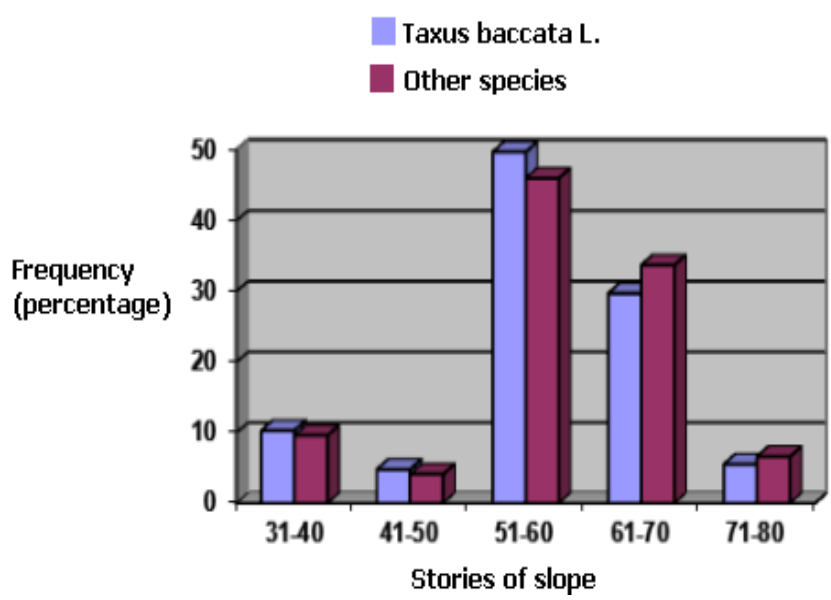

Fig. 5. The interrelationship between the slope of foothill and the frequency of regeneration in the Kolaleh habitat

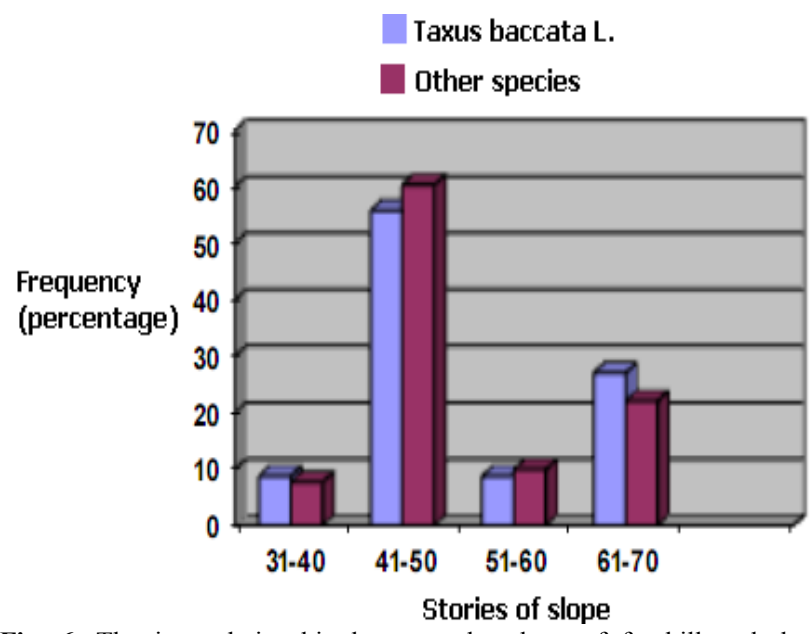

Fig. 6. The interrelationship between the slope of foothill and the frequency of regeneration in the Kouran habitat
7. The comparison of the regeneration of Taxus baccata L. in different heights

In order to compare the average number of the regeneration and the measured qualitative specifications with different heights, the non-parametric Chi-square test (x2) was used. The results of the test show that with a probability of $95 \%$, the regeneration of Taxus baccata L. has a significant discrepancy with the different heights studied in the Kolaleh and Kouran habitats, while there's no significant discrepancy between the average health and vivacity of the Taxus baccata L. saplings with the altitude stories in both habitats.

\begin{tabular}{l|l|l|l|l|l|l}
\hline \multicolumn{7}{c}{ Height above the sea level } \\
\hline Habitat & Specification & $\begin{array}{l}1300- \\
1400\end{array}$ & $\begin{array}{l}1200- \\
1300\end{array}$ & $\begin{array}{l}1100- \\
1200\end{array}$ & $\begin{array}{l}\mathrm{x}^{2} \\
\text { statistic }\end{array}$ & \\
\hline \multirow{3}{*}{ Kolaleh } & & Regalue & \\
\hline & Health & 280 & 360 & 60 & 22.76 & $0.000^{*}$ \\
\cline { 2 - 8 } & Vivacity & 229.5 & 270 & 55 & 2.33 & $0.678^{\text {n.s }}$ \\
\hline \multirow{3}{*}{ Kouran } & Regeneration & 180 & 274.5 & 63 & 21.94 & $0.003^{\text {n.s }}$ \\
\cline { 2 - 8 } & Health & 161.1 & 245.7 & 56.25 & 0.821 & $0.936^{\text {n.s }}$ \\
\cline { 2 - 8 } & Vivacity & 120.6 & 183.6 & 42.3 & 6.308 & $0.177^{\text {n.s }}$ \\
\hline
\end{tabular}

Tab. 1. The values of (x2) test as to the comparison between the qualitative and quantitative features of Taxus baccata L. with different heights

* Significant in the level of 5 percent

$\mathrm{n} . \mathrm{s}=$ non-significant

\section{The comparison of the regeneration of Taxus baccata L. in different dimensions}

The average qualitative and quantitative features investigated for the sample plots located in different parts of the region and the statistical test carried out is presented in the table 2 by which it can be observed that the average regeneration, health and vivacity of the Taxus baccata $L$. saplings in the northern direction of both habitats is higher than the other directions. Moreover, the results arising from the $\mathrm{x} 2$ test show that there's a significant discrepancy between the number of regenerations in the two habitats and the directions studied in the $95 \%$ contingency level. However, no significant discrepancy was observed between the features of health and vivacity of the saplings and the different dimensions.

\begin{tabular}{|l|l|l|l|l|l|l|}
\hline & & \multicolumn{3}{|l|}{ Geographical dimensions } & & \\
\hline Habitat & Specification & Northeast & Northwest & North & $\begin{array}{l}\mathrm{x}^{2} \\
\text { statistic }\end{array}$ & p-value \\
\hline \multirow{3}{*}{ Kolaleh } & Regeneration & 135 & 187 & 587 & 45.20 & $0.000^{*}$ \\
\cline { 2 - 7 } & Health & 119 & 172 & 529 & 2.71 & $\begin{array}{l}0.610 \\
\text { n.s }\end{array}$ \\
\cline { 2 - 7 } & Vivacity & 91 & 121 & 405 & 4.38 & $\begin{array}{l}0.356 \\
\text { n.s }\end{array}$ \\
\hline \multirow{3}{*}{ Kouran } & Regeneration & 18 & 94.5 & 405 & 26.77 & $0.026^{*}$ \\
\cline { 2 - 7 } & Health & 16.2 & 84.6 & 362.7 & 2.14 & $\begin{array}{l}0.711 \\
\text { n.s }\end{array}$ \\
\cline { 2 - 7 } & Vivacity & 12.15 & 63.45 & 271.35 & 1.84 & $\begin{array}{l}0.765 \\
\text { n.s }\end{array}$ \\
\hline
\end{tabular}

Tab. 2. The values of (x2) test as to the comparison between the qualitative and quantitative features of Taxus baccata L. with different dimensions

* Significant in the level of 5 percent

n.s = non-significant

9. The comparison of regeneration Taxus baccata $L$. in different slopes

Statistical comparison between the number of regenerations and the qualitative specifications of health and vivacity of the Taxus baccata L. saplings in different slopes shows that there's no significant discrepancy between the qualitative 
and quantitative features studied and the different slopes in the contingency level of $95 \%$.

Tab. 3. The values of $(x 2)$ test as to the comparison between the qualitative and quantitative features of Taxus baccata L. with different slopes

\begin{tabular}{|c|c|c|c|c|c|c|c|c|}
\hline & & \multicolumn{5}{|c|}{ Slope (percent) } & \multirow[b]{2}{*}{$\begin{array}{l}\mathrm{X}^{2} \\
\text { statisti } \\
\mathrm{c}\end{array}$} & \multirow[b]{2}{*}{$\begin{array}{l}\text { p- } \\
\text { value }\end{array}$} \\
\hline Habitat & $\begin{array}{l}\text { Specificatio } \\
\mathrm{n}\end{array}$ & $\begin{array}{l}71- \\
80\end{array}$ & $\begin{array}{l}61- \\
70\end{array}$ & $\begin{array}{l}51- \\
60\end{array}$ & $\begin{array}{l}41- \\
50\end{array}$ & $\begin{array}{l}31- \\
40\end{array}$ & & \\
\hline \multirow{3}{*}{$\begin{array}{l}\text { Kolale } \\
\text { h }\end{array}$} & $\begin{array}{l}\text { Regeneratio } \\
\mathrm{n}\end{array}$ & 40 & 215 & 360 & 35 & 60 & 61.066 & $\begin{array}{l}0.19 \\
4^{\text {n.s. }}\end{array}$ \\
\hline & Health & $\begin{array}{l}36 . \\
5\end{array}$ & 197 & 330 & 32 & 69 & 6.178 & $\begin{array}{l}0.62 \\
6^{\text {n.s }}\end{array}$ \\
\hline & Vivacity & 30 & $\begin{array}{l}161 . \\
5\end{array}$ & $\begin{array}{l}270 . \\
5\end{array}$ & 26.5 & 56.5 & 10.702 & $\begin{array}{l}0.21 \\
9^{\text {n.s.s }}\end{array}$ \\
\hline \multirow[t]{3}{*}{ Koulan } & $\begin{array}{l}\text { Regeneratio } \\
\mathrm{n}\end{array}$ & - & 108 & 45 & $\begin{array}{l}274 . \\
5\end{array}$ & 90 & 0.657 & $\begin{array}{l}0.88 \\
3^{\text {n.s }}\end{array}$ \\
\hline & Health & - & $\begin{array}{l}96.7 \\
5\end{array}$ & 40.5 & $\begin{array}{l}245 . \\
7\end{array}$ & $\begin{array}{l}80.5 \\
5\end{array}$ & 7.146 & $\begin{array}{l}0.30 \\
8^{\text {n.s }}\end{array}$ \\
\hline & Vivacity & - & $\begin{array}{l}72.4 \\
5\end{array}$ & $\begin{array}{l}30.1 \\
5\end{array}$ & $\begin{array}{l}183 . \\
6\end{array}$ & 60.3 & 1.431 & $\begin{array}{l}0.96 \\
4^{\text {n.s }}\end{array}$ \\
\hline
\end{tabular}

$\mathrm{s}=$ non-significant

\section{Argument and conclusion}

Taxus baccata L. is considered to be one of the most environmentally valuable species of Arasbaran. In Arasbaran, this tree has been removed from many forest areas and is only observable in some parts. The majority of the peduncles of Taxus baccata L. is coppice and mostly in the growing stage of sapling and each peduncle can be seen as a single group. According to the results yielded from studies on the habitats of Taxus baccata L. in Arasbaran (habitats of Kolaleh and Kouran), it can be claimed that this tree is climatically more flexible and bendable. Although it's a species which appeals to humidity and the inadequacy of humidity extremely limits its development and dissemination in the dry habitats, this tree has got adapted to the difficult ecological situation of the region in such a way that in terms of needing humidity, it endures the minimum amount of precipitation ( $404.7 \mathrm{~mm}$ ) and can be observed as forest masses. In the habitats of Taxus baccata L. in the Arasbaran region, the amount of precipitation will raise with the increasing of height above the sea level which in turn will add to the quality and number of Taxus baccata L. trees per hectare in these regions. Having in mind the climatic situation and the presence of a three-month-long period of drought in these regions, it seems that the number of foggy days and the humidity resulting from it is effective in the growth of Taxus baccata L. trees. The humidity resulting from fog (invisible rain) is more effective in the emergence of forests in general and the masses of Taxus baccata L. in particular in these regions. Investigations on regeneration also showed that in each hectare of the areas studied, there were 500 saplings of Taxus baccata L. and 4402 saplings of other species the reason for which may be the physicalchemical suitability of the soil and appropriate climatic and environmental conditions. This finding is in line with the results of studies by other researchers such as Ghanbari Sharafeh (2005) who put the number of Taxus baccata L. in the Ilgene Chay region of Arabsaran forests and other species at 520 and 3797 respectively. Moreover, these findings are highly promising as compared to the other habitats of Taxus baccata L. such as Afra Takhteh which have several maternal peduncles and seeds with high viability, given that in Lesaani's research (1988) 50 saplings were mentioned for each hectare and Hosseini (2000) has mentioned 50 Taxus baccata L. saplings for each hectare. In another study, Lesaani (1999) has estimated the number of Taxus baccata L. saplings in the Pouneh Aram habitat to be less than 40 single roots per hectare. As to the growth form of Taxus baccata L., $71.6 \%$ of the peduncles were coppice and $28.47 \%$ were high forest trees. In a research study done in the habitats of Taxus baccata L. in the Arasbaran forests, Ghanbari Sharafeh (2004) has estimated that $73.2 \%$ of the peduncles were coppice and $26.9 \%$ were high forest trees which is approximately similar to the findings of the present study. Today, with the protections which have been provided, especially in the Kolaleh region, $55.9 \%$ of the Taxus baccata L. saplings are high forest trees and $44.1 \%$ are coppice. In a study which Ghanbari Sharafeh (2004) has carried out in this habitat, $52 \%$ of the Taxus baccata L. saplings are high forest trees and $48 \%$ are coppice. Moreover, in a study which Barzegar has done in this region (2001), 53.6\% of the Taxus baccata L. saplings were estimated to be high forest trees, which is similar to the results of the present research. But due to the lack of protection and absence of forester in the Kouran habitat and as a result of human intervention and presence of the livestock, we are witness to the decrease of regeneration of Taxus baccata L. high forest trees in such a way that only $25 \%$ of the Taxus baccata L. saplings in this region are high forest trees and the rest of reproductions have coppice roots which is due to the excessive pressure of the livestock and cutting of the trees for rural uses, causing the woods to become mostly coppice. Due to the cutting of maternal peduncles, only a small amount of seed saplings are produced most of which is eaten by the livestock and get removed in the different growth stages. Therefore, it's better to preclude such a process by adopting necessary measures. According to the studies carried out, the greater part of natural regeneration of Taxus baccata $L$. in the habitats studied can be observed in the northern foothills with a covered crown (of about 50-90\%) and grass coverage of less than $10 \%$, because in such foothills, there's more humidity and a better thermal and light regime and less competition between grass coverage and regeneration.

In a study by Hulme (1996) on the limitations of herbal plants on the natural regeneration of Taxus baccata L. in the coastal regions of the $\mathrm{UK}$, it was pointed out that in regions with a low grass coverage, the seeds of Taxus baccata L. increase by 6 percent. Also in a study by Amirghassemi (2001) carried out in the Setan Chay region of Arasbaran forests, it was stated that the majority of regeneration $(44.4 \%)$ takes place in the grass coverage of less than $10 \%$. Furthermore, in the $51-60 \%$ slope and the altitude of 1200 1300 meters above the sea level in the Kolaleh habitat and the $41-50 \%$ slope and the altitude of 1400-1500 meters above the sea level in the Kouran habitat, the main part of Taxus baccata L. regeneration takes place which declines with the increasing of height and slope as a result of problems arising from the establishment of saplings and erosion of soil and ecological and climatical factors. Therefore, it's recommended that such regions which have a more suitable situation in terms of regeneration be protected and subject to proper silvical growth operation. 


\section{References}

1. Amirghassemi, F., 2001, The investigation of the structure of revitalization of Arasbaran forests in the Setan Chay studied area, Iran's Institute for Research on Forests and Pasturages Publication, p. 47

2. Barzegar, A., 2002, The investigation of the habitats of Taxus baccata L. in the Arasbaran forests, M.A. dissertation, the University of Guilan, p. 55

3. Hosseini, M., 2000, The investigation of the ecologic power of Iran's indigenous acerate-leaf forests, the Ph.D. dissertation of forestry, Tarbiat Modarres University, p. 161

4. Osareh, M. H., 2007, The investigation of the explanatory structure of rhizogenesis and the causes of late production of roots in the scions of Taxus baccata L., Pajoohesh-va-Sazandegi Journal, vol. 74, p. 115

5. Farsi, M., 2008, An introduction to the application of statistics in agriculture and biological sciences, Mashhad Agricultural Jihad Publications, p. 272

6. Ghanbari Sharafeh, A., 2005, The investigation of the ecologic sequence of Taxus baccata L. masses in the Arasbaran forests, M.A. dissertation, the University of Tehran, p. 125
7. Lesaani, M. R., 1988, The decadent course of Iran's Taxus baccata $L$. forests and techniques for revitalizing them, Zeitoun Magazine, vol. 88, pp. 30-31 and 47-48

8. Lesaani, M. R., 1999, Taxus baccata L., Iran's Institute for Research on Forests and Pasturages Publication

9. Yousefpour Rashti, M., 1998, The investigation of regeneration of Taxus baccata L. and the role of the quality of seed in its revitalization, M.A. dissertation, the University of Guilan, p. 82

10. Boyd, J., 1995, Natural Regeneration, University of Wisconsin.

11. Hulme, P., 1996, Natural regeneration of yew (Taxus baccata L.) microsite, Seed or herbivore Limitation, Department of Biological Science Durham England, p. 38

12. Plaisance, G., 1979, L IF (Taxus baccata) Fort Prive, 126: 34 47.

13. Prioton, J., 1979, Etude biologiyue et ecologique del IF (Taxus baccata) en Europe occidental, Foret Prive, 128: 19- 34, I portie, Foret Privec, 128: 1937. 